\title{
Kuidas kujuneb pillimeeste rahvapärane repertuaar
}

Guldžahon Jussufi

Teesid: Käesolevas kirjutises püüan jälgida, millised on eesti rahvapärase muusika täienemise teed ja miks mõned lood, aga teinekord ka terved kihistused, aja jooksul pillimeeste repertuaarist välja langevad. Mu tähelepanu koondub peaasjalikult kandleviisidele, kuigi rahvamuusika varasalves täidab kannel ainult ühe nurgakese. Märkides muutusi repertuaaris, peame leppima tõsiasjaga, et alati ei ole see areng madalamalt astmelt kõrgemale. Muutused võivad olla ka mõnesuguse mandumise ja sellele järgneva kadumise tunnuseks. Ometi ei saa muutusi jagada soovitavaiks ja ebasoovitavaiks - muutused on paratamatus.

Märksõnad: rahvalik laul, kannel, akordion, lõõtspill, omalooming, rahvapärane repertuaar.

\section{Sissejuhatuseks}

Juba mõnda aega olen ma teinud ettevalmistusi Lõuna-Eesti kandlelugude analüüsimiseks muusikateooria vahenditega. Tulemusena peaks saama selgemaks, milline on sisemine seos vanemate eesti viiside ja nüüdisajal mängitava repertuaari vahel. Esialgu on mu tegevus piirdunud helisalvestiste noodistamisega, milleta ei saa rahvamuusika uurimisel läbi. Rahvaluule arhiivi fonoteegi kogude kandleviisidest on siiani noodikirja kantud kõigest kolm protsenti (Kalda 2001: 121), nii et selle aeganõudva töö eest pole pääsu. Pealegi on olemasolevad noodistused teostatud ühehäälselt tähtharmoonia märkidega, mis ei näita muusikapalade faktuuri tegelikku joonist. Ainus erand tundub olevat soome folkloristi Otto Armas Väisäneni 1912. ja 1913. aastal salvestatud ja hiljem noodistatud materjal (Kalda 2001: 124-138).

Ettevalmistava töö käigus ilmnes, et varem trükis avaldatud rahvaviisid ei esine tänapäeval mängitavate kandlelugude hulgas. ${ }^{1}$ Ainsa tõepärase seletusena võib kõne alla tulla, et mingi suurem või väiksem osa eesti rahvamuusikast on jõudnud käibelt kaduda. Miks see nii juhtus ja mis päritolu on täna- 
päevased lood? Milline osa neist on pillimeeste omalooming? Kas mõnel pool mängitakse teisi lugusid kui kusagil mujal?

Tänapäeval on kasutusel terve rida rahvaste muusikaloomingut ja -eelistusi tähistavaid mõisteid nagu rahvamuusika, pärimusmuusika, folkmuusika, populaarmuusika, rahvalik muusika (Särg 2002: 33-37). Kõigil neil mõisteil on oma spetsiifiline sisu, seetõttu oleks kohane kohe algul selgeks teha, millistega neist puutume kokku järgnevas kirjutises. Nendeks mõisteteks on 'rahvalik laul' ja 'rahvalik muusika', mis tähistavad rahvaks peetava rühma hulgas tegelikult levinud muusikat, millel puuduvad teised rahvamuusikale tarvilikuks peetavad tunnused (nt pole traditsioonilises stiilis, pärinevad trükiallikast vm) (Särg 2002: 34).

\section{Allikatest}

Kõigepealt veidi asjasse puutuvat statistikat materjali kohta Eesti Rahvaluule Arhiivi fonoteegis, mis on minu peamine infoallikas. Kandlemuusika salvestisi leidub alates 1912. aastast, mil Eestis, sealhulgas Setumaal, käis Otto Armas Väisänen. Ajaliselt järgmised salvestused on teinud Eduard Oja 1929. ja Karl Leichter 1930. aastal. Aastail 1932-1938. tegelesid salvestamisega Herbert Tampere ja August Pulst. Pärast pikemat vaheaega jätkas 1959. aastal seda tööd Aino Struzkin ja seejärel on rahvamuusikat salvestatud vastavalt etnomusikoloogia osakonna uurimistöö vajadustele pidevalt.

Folkloristide huviorbiiti jäänud kandlemängijate koguarv ligineb kahesajale. Valdav enamus mängijatest olid muusika helikandjaile salvestamise ajal üle seitsmekümne aasta vanad (sünniaeg 1890. ja 1920. aastate vahel). Alla viiekümneseid võib üles lugeda kahe käe sõrmedel. Päris nooreks saame nimetada ainult ühte pillimeest, kellel 1982. aastal oli täitunud viieteistkümnes eluaasta.

Mõni neist on uurijaile mänginud mitu korda, sealjuures mitmed lood korduvad erinevail aastail.

1929. aastal sündinud Hargla pillimehe Eduard Kasaku lugusid on salvestatud 1957. (RKM, Mgn II, 80), 1976. (RKM, Mgn II, 4097, 4098) ja 1990. aastal (RKM, Mgn II, 4450), kokku 41 lugu.

Ivo Kongot Otepäält on mänginud 1958. (RMK, Mgn ER, 8) ja 1982. aastal (RKM, Mgn II, 3559, 3565) kokku 48 lugu.

Tartlane Leonhard Kuusksalu (sünd 1914 Põlvas) esitas 1965. (RKM, Mgn II, 1071, 1072, 1074, 1075), 1970. (RKM, Mgn II, 1729) ja 1971. aastal (RKM, Mgn II 2002, 2003) kokku 43 lugu. 
Kõige enam on kandlemängu salvestatud 1981. aastal Enno Kunnuselt (sünd 1936) Vastseliinas - 81 lugu (RKM, Mgn II, 3644, 3645, 3648, 4438, 4441, 4443).

Samal ajal leiame terve hulga pillimehi, kellelt on fonoteeki jäänud kõigest 1-2 lugu (Kalda 2001: 114-117).

Salvestised pärinevad Eestist väga ebaühtlaselt. Näiteks Otepää ja Vastseliina kihelkonnas on tehtud vastavalt 253 ja 216 , Viljandis aga 4 ja Tartumaal 3 salvestust (Kalda 2001: 118-119). Seetõttu on võimatu teha järeldusi lugude populaarsuse kohta eri paigus. Menukaimad lood on levinud üle Eesti, olenemata päritolupaigast. Näiteks on "Savikoja venelane" Saaremaal niisama tuntud kui Kagu-Eestis, kust see kunagi liikvele läks. Ja mis üsnagi üllatav mujal on seda lugu fikseeritud instrumentaalsel kujul, Saaremaal aga lauluna (Sünter 1997: 8).

Rääkides pillimuusika salvestustest, ei saa jätta mainimata uurijaid, kes selle töö läbi viisid. Kataloogis registreeritud pealkirjade järgi sarnaseid lugusid leida ei olegi mõnikord kuigi lihtne. Uurijate hulgas leidub neid, kes piirduvad žanri nimetuse märkimisega (nt valss, polka, fokstrott, polkamasurka), samas kui teised on püüdnud anda loo võimalikult täpse pealkirja. Nähtavasti põhjustasid sellise ebajärjekindluse teadlaste erinevad huvid: üks lähenes rahvamuusikale tantsu seisukohalt, teine aga üldisematel eesmärkidel.

Lisaks ERA fonoteegi materjalidele olen kasutanud endise Viljandi Kultuurikolledži toonase üliõpilase Aleksander Sünteri kursusetöö Uuem (rahva) laul ja pillilood 60-aastaste ja vanemate inimeste repertuaaris 1990-ndatel Jaani kihelkonnas Saaremaal (Sünter 1997) tarbeks tehtud salvestisi Saaremaalt ja Ilmar Hellamaa sissemängitud CDd Kandlemeister (Hellamaa).

\section{Lähtepunkt}

Minu varasemad kokkupuuted eesti rahvamuusikaga on piirdunud tegevusega rahvatantsurühma saatjana kandlel ja klaveril. Otsides vastust küsimustele rahvapärase repertuaari kujunemisest tuli mul võtta põhjalikumalt käsile eesti muusikalugu laiemas, kultuuriloo kontekstis.

Alustuseks kordan lühidalt üle Juhan Aaviku ja Herbert Tampere sõnastatud seisukoha eesti rahvamuusika jagunemisest kolme kihistusse: arhailine regiviis, hilisem rahvaviis ja uuem rahvaviis (Aavik 1965: 63). Runoviisi meloodia liigub tavaliselt ilma hüpeteta kitsas, tertsi, kvardi, harvemini kvindi ulatuses, laulu iga sõnasilp on viisistatud ühe vastava heliga. Need omadused, hüpete puudumine või esinemine ning kitsas ulatus saab olla viisi vanuse määramise kriteeriumiks (Aavik 1965: 61). 
Hilisema aja viiside olulisimateks tunnusteks peab J. Aavik laiemat ulatust, vaheldusrikkamat rütmi ja teisenenud vormi, kus meloodika kannab juba kunstmuusika lauseehituse mõjusid (Aavik 1965: 62).

XIX sajandi teisel poolel ilmus jõuliselt uuem rahvaviis, mis tänapäeval on tuntud rahvaliku muusikana. See on kas otseselt laenatud rahvapärastelt kunstlauludelt (ka võõrailt) ja tantsuviisidelt või nende eeskujul loodud (Tampere 1999: 11). Selline üldine arenguskeem peaks kehtima kõigi rahvaste muusikakultuuride kohta, kuigi ehk mitte range astmestiku kujul.

On üsnagi usutav, et eesti rahvaviiside vanema kihistuse hääbumist soodustas muude kultuuriliste mõjurite kõrval ka hernhuutliku ehk siis vennastekoguduste usuliikumise levik. Hernhuutluse mõjul hakati koolides arendama laulu-ja muusikakooride tegevust, mis sai eelastmeks hilisematele suurtele rahvuslikele laulupidudele (Ilja 1995: 72). Kohe, kui liikumine XVII esimesel poolel eestlaste hulka jõudis, hakati laule sepitsema, neile viise looma ja laulma, seda eriti Urvastes (Ilja 1995: 211). Kogudustes korraldati palvetundide eel spetsiaalseid laulutunde, millest puudumine pidi olema suurem kaotus, kui kolme jutluse vahele jätmine. Laulu ja muusikat hinnati väga kõrgelt, see oli koguduse elus nagu igapäevane leib, millega koos hommikul tõusti ja ôhtul magama mindi (Ilja 1995: 210). Kuid see oli juba väljastpoolt sisse toodud muusika. Euroopalike muusikariistade ja viiside levimine oli seega mitte niivõrd järjekindla arengu, kuivõrd organisatoorse töö tulemus. Miks aga rahvas uue muusika vaimustusega vastu võttis, seletub vist selle rõõmsameelse iseloomuga. Eestist usukeskusesse saadetud aruannetes satub aina lauludele ja laulmise mainimisele (Ilja 1995: 211). R. Põldmäe märgib, et hernhuudi vennastekiriku lauluvara hulka lisandus isegi Ober-Lausitzi rahvamuusikat, nii et hernhuutlik kirikulaul kujunes üsna elavaloomuliseks ja selle kiriku vastased sü̈̈distasid kogudust koguni tantsu- ja lorilaulude kasutamises (Põldmäe 1988: 67). Üks hernhuutlik allikas kiidab eestlasi, et nad on võimelised omandama kõige keerukamaidki meloodiaid. Nad valmistavad omale väikesi kandleid ja õpivad iseseisvalt mängima (Põldmäe 1988: 68). See napp märkus peaks ühtlasi viitama ka sellele, et laul ja kandlemäng olid vanemal ajal omavahel orgaaniliselt seotud.

Hernhuutlust vennaste endi arhiivide toel põhjalikult uurinud V. Ilja ja R. Põldmäe näevad asju otsekui seestpoolt: nende hinnangud on tugeva positiivse alatooniga. Tõepoolest, vennastekoguduste osa rahvahariduse tõstmisel, euroopalike orkestrite ja laulukooride asutamisel on vaieldamatu, kuid samal ajal muutus paratamatuks vanade rahvalaulude- ja viiside kadumine. Seda ei saa mingil moel panna hernhuutluse süüks, kahtlemata toimis mitmeid teisigi tegureid, mis samuti soodustasid muutusi rahvapärases muusikas. On isegi põhjust olla tänulik hernhuutlastele, sest nende hoolikalt säilita- 
tud arhiivide najal osutub võimalikuks jälgida eesti rahvamuusika arengu ühte etappi. Kui kultuurivalda tungib mingi uus komponent, mille rahvas omaks võtab, ei saa vana - seega aegunu - kesta eriti kaua. Nii püsis vanem rahvalaul üksikute lauljate najal veel XX sajandi esimese veerandi, kuid nüüdseks on see ammugi traditsioonilisest kasutusest kadunud.

Kriitiliste uurijate silma on puutunud mitmeid hernhuutluse varjukülgi. Võitlus paganluse rudimentidega viis pärimuskultuuri vaesumisele. Liikumine muutus aina agressiivsemaks ja kujunes usumäratsemiseks. (Gnadenteich 1995: 68) Näiteks Urvaste õpetaja J. Ch. Quandt hävitas 1736. aastal kõigest paari nädala jooksul 24 ohvrikohta (Gnadenteich 1995: 70). Lõhuti ohvrikive, rahvapäraseid ehteid ja muusikariistu. Häbiväärne laul, tants, torupill ja karglemine langesid ära iseenesest, ilma sunduseta (Põldmäe \& Tampere 1938: 10). Toimus midagi sarnast nagu luterluse tulekul 200 aastat varem, kui uue usu pooldajad rüüstasid katoliku kirikuid ja hävitasid pühapilte (Gnadenteich 1995: 38). Helme kihelkonna kohta märgiti 1888. aastal, et lääne ja põhja pool on vanavara veel hästi rohkesti leida; lõuna-ja ida-ja kesk-kihelkonnas mitte peaaegu sugugi, sest see ring oli ja on hernhuutite (vennastekoguduste) pesapaik, ja kus need sigisivad, sealt kadus vanavara suutumaks ära (Tampere 1999: 13). Samal moel on käitunud äärmuslikud religioossed liikumised kõikjal sõltumata ajajärgust. ${ }^{2}$

"Joriseva" torupilli sidumine põrgulike jõududega ja võitlus selle vastu ei ole üllatav. Kuid miks loobus rahvas kandlest, mida pühakirjas on palju kordi ülivõrdes meenutatud?

Taawida-pill, Jeesu-pill, kannel, om kõige vanemb mänguriist maa pääl. Kuning Taavid om tima Jumala käest saanu ja Jumal esi om Taawidale tima löömist kätte opanu. Ka Jeesuke mängse seo pilli pääl ja näüdi ristinemisile timä löömist.

Nii ülistas kannelt setu pillimees 1910. aastal ja samas leiame ka vastuse oma küsimusele, miks loobuti kandlest:

Selle mängitigi wanal aal kannelt ennegi püha aal ja köie inämb talistepühil, too om Toomapäivast wastseastagani. Muidugi mängiti ka saajne ni kirmaskil. A inämbiki püho aal. Aastaga 70 iist ol siin üts wäega kuulsa kandlelööja, Härma külä Iwwani Нӧödo (Федорь Ивановичъ), mu vanaesä, a kannel sais timäl terwe aasta aigu aidah wiljäsalveh, ei mängi kunagi; a tul Toomapäiw, toodi haina ni hole tarrehe, läti õdangul wanaesä aitahe ja tõi uma kadajadse kandle kodo, mõsi käe ni suu puhtas, isti järje pääle ja sis nakse mängma, ja ku illosahe!... Ole ei inämb säänest mängmist kohnil kulda, ja nii iki iga päiw kooni wastse aastagani; 
sis ta wei kandle jällegi aita salwehe ja ei too enne wälla kui suistepühil, wai arokõrd, kui mõni kallis külaline jotse tulema, sis mängiti ka, a iki weidemb ku Toomapäiwal. Timä mängoloo olliwa wäega illosa ja haleda. (ERM 47, nr. 71).

Ilmselt täitis kannel eestlaste poolpaganlike riituste juures mingeid kultuslikke funktsioone ning ristiusu kindlustamise huvides oli vaja temast vabaneda. Milliste vahenditega see eesmärk saavutati, on selguseta, kuid vana tüüpi kannel oli käibelt kadunud XIX sajandi alguseks, jäädes püsima vaid Setu- ja kohati Võrumaal (Aavik 1965: 44).

Uku Masingult leiame kaudse viite, mis kinnitab, et kandlega olid seotud mingid üleloomulikud jõud: Mainitav on veel veehaldjate, kuid ka teiste seos muusikaga. Ida-Karjalas kõneldakse, et kes tahtis õppida kannelt mängima, pidi istuma kolm ööpäeva saunaahjul, siis tuli õpetaja. Kui ta aga siiski ei tulnud, tuli oodata üheksa ööpäeva, siis ta tuli kindlasti ja õpetas (Masing 1998: 139).

Kandlemängu õppimisega kaasas käinud rituaal - saunalaval istumine ja õpetaja ootamine - õigustab oletust, et kandlemängija omandas üleloomuliku väe ja jäi vaimuilmaga seotuks ka pärast õpingute lõppu.

\section{Muusika jääb}

Laul ja pillilood, kuigi need kõlasid juba võõrsilt toodud eeskujude järgi, muidugi jäid. Nende kandepind ehk isegi kasvas, samal ajal kui vana pärimus vajus üha enam unustusse. Esiplaanile tõusis mitmehäälne koorilaul, torupilli juhtpositsioon tantsumuusikas taandus viiuli ees. Kandle koht seisis MandriEestis pikka aega tühjana. XIX sajandi lõpul hakkasid levima akordion ja lõõtspill ning nende, eriti akordioni, edu jättis teised muusikariistad kaugele selja taha. Umbes samal ajal naasis ka kannel, kuid juba uuel, nn simbli kujul. Nüüd oli kandlel 20-30 keelt ning mängida sai keerukamaid ja suurema diapasooniga lugusid kui vanal viie-kuuekeelelisel pillil.

Kandlemuusikaga tegeldes torkab peagi silma, et tunduv osa kandlerepertuaarist kordab mõnda lauluviisi. Isegi setu kanneldajate mängitud kirikukellade imitatsioonide kohta pole võimalik öelda, et need on puhtal kujul kandlelood. ${ }^{3}$ Pigem on tegu jäljendavate häälitsuste esitamisega instrumendil. Selle kohta leiame kinnitust Jaan Lattiku mälestusteraamatus Minu album.

Meil oli talus üks aastapoiss, kelle eesnimi oli Vassil. Tema oli vere poolest venelane, ka õigeusku loomulikult. Tuli meile Käärikmäe savilöövi juurest, kus ta isa oli tööl. Mängis hästi harmoonikat. Oli teisel kõva 
bassihääl. Eesti keel selge kui savi, aga vene murrak juures. Laulis teine igasuguseid viise ja laule. [---] Vassil seletas meile ka, kuidas Valga vene kiriku kellad löövad - Rasumovski, Kovalevski, Kalkin, Kalkin... Need olid vene kaupmeeste nimed. Seda lugu ma kuulsin Valgas ja võin kinnitada, et see niiviisi käis (Lattik 1960: 92-93).

Rahvamuusika ladestusi - ei varasemat ega hilisemat - pillimeeste tavarepertuaaris ei esine. Need rahvamuusika kihistused on tänapäevaks jõudnud rahva teadvusest kaduda ja saada professionaalsete rahvamuusikute, aga ka pärimuskultuuri harrastajate omanduseks. Suurema osa arhiivi talletatud kandlelugudest moodustavad rahvalike laulude instrumentaalversioonid.

Puudutanud pillimeeste repertuaari muutumise teemat, jõuame varem või hiljem rahvaliku laulu juurde. See varamu sisaldab paljude rahvaste, aga põhiliselt siiski mõne kindla autori loodud meloodiaid, mis sobivad eestlaste muusikalise maitsega. Oma leviku algperioodil pidi rahvalik laul olema otsekui eelneva laulutraditsiooni jätkuks, nii et rahva ilumeel selle omaks võttis. Õigupoolest on rahvalik laul valikuline, ent samal ajal üsna juhuslik repertuaar: mitte iga kaunist lauluviisi ei võeta omaks. On loodud palju muusikapalasid, mis võinuksid leida koha eesti rahvaliku muusika hulgas, kuid miskipärast on sellest kõrvale jäänud. Silmas tuleb pidada ka seda, et võõrsilt tulid ainult viisid, sõnu kirjutati ise. Ei tohiks olla liiast oletada, et rahvaliku laulu elujõu määrab õnnestunud tekst. Nähtavasti pole pelgalt juhus, et kolmveerand sajandit saadab edu mitmeid John Pori ja Sergius Lipu sõnadega laule. Küllap need "värsisepad" aimasid, mis tõstab inimese tuju.

Küsimuse võiks püstitada laiemaltki: milline on tänapäeva rahvaliku muusika side varasema rahvamuusikaga? Kas alles võõramaiste mõjutuste najal jõudis eesti muusika euroopa kultuuriruumi või kuulub see sinna esiaegadest peale? See oleks omaette teema, mis käesoleva artikli raamidesse ei mahu. Igal juhul on friisi viis "Läänemere lained" eestlasele meelepärane, aga geograafiliselt lähedase Venemaa lood mitte eriti. Kõrvalt vaadates tundub, et eesti ilumeel ei talu bravuuritsemist, vaid hoiab meloodilisuse poole.

\section{Mida mängitakse}

Tehes ERA fonoteegi najal väikest statistikat, näeme, et kandlemeeste lemmiklugudeks on viimase poole sajandi jooksul olnud "Kaera-Jaan", "Padespann" ("Nadinunnadi"), "Perekonna valss" ("Üks vanamees raius üht jämedat puud"), "Viljandi paadimees", "Roosiaias", "Hulkuri valss", "Kui naanõ minno pahandas", "Kas mäletad kevadet õites", "Postipoiss", "Sonny-boy”, "Kaugel-kaugel, 
kus on minu kodu". Teisalt kuuluvad samad lood ka lõõtspilli- ja akordionimängijate repertuaari hulka.

Rahvalikud laulud ja nende instrumentaalversioonid ongi see muusika, mis kõlab traditsioonilisema eluhoiakuga inimeste pulmades, kodustel pidudel ja koosviibimistel. Väga hea ülevaate rahvalikust laulust annavad Inda Kõiva koostatud kogumikud Lustilaulik I (Lustilaulik 1999) ja II. ERAs talletatud rahvalik laul mõne pilli saatel või instrumentaalversioonina kõlab enamasti täpselt sellisel kujul, nagu see on neis laulikuis noodistustena esitatud. ${ }^{4}$ Instrumentalistid, kas siis lõõtspillil, akordionil või kandlel, mängivad lauluviise, lisades neile akorde.

Kuid leidub pillimehi, kes tunnetavad mõnda lugu omamoodi ja tulemuseks võib olla täiesti uus teos. Näiteks sujuva ja paindliku liikumisega valss “Joo, sõber joo" (Lustilaulik 1999, nr 367), on väga sobiv laulmiseks. Seda laulu, kus 8-taktilisele $\mathrm{ABAB}$ vormis salmidele järgneb 8-taktiline $\mathrm{CC}_{1} \mathrm{DD}_{1}$ vormis refrääniosa, saaks kandlel esitada ilma mingite muudatusteta, kuid kandlemängija Elmar Raudsepa esituses (RKM, mgn ER 14) kõlab lugu hoopis teisiti: puuduvad valsile iseloomulikud pikad vältused, nende asemel tuleb terve rida ühe- ja kohati poolelöögilisi noote. Taktimõõt on $3 / 4$ asemel $3 / 8$. Viisi rütmikuju on niivõrd muutunud, et valsilikkust meenutab rohkem ühehäälne saade, kus õrnalt on rõhutatud takti esimest lööki. Sisuliselt on see improvisatsioon antud laulu teemal ülesehitusega $\mathrm{AB} \mathrm{A}_{1} \mathrm{~A}_{2} \mathrm{CC}_{1}$, mida korratakse kolm korda. "Joo, sõber, joo" on Elmar Raudsepa interpretatsioonis kaunis ja virtuoosne pala, kus esile tõuseb pillimehe isikupära ja loominguline suhtumine muusikasse (vt noodinäide 1).

Ilmar Hellamaa CD-1 Kandlemeister leiame kolme liiki näiteid: 1) lauluviisi muutmata on lisatud akordisaade; 2) viisi on kergelt muudetud; 3) viisi on põhjalikult muudetud. Kandlel mängitud “Läänemere lained” (Lustilaulik 1999, nr 2) erineb laulust väga vähe. Loo struktuur jääb samaks. Viisis esinevad pikad helid jaotab kandlemees kohati lühikesteks, aga kadentse mängib samuti nagu seda tehakse lõõtspillil või akordionil. Üldse on sisse toodud käike, mis rohkem iseloomustavad lõõtspilli- ja akordionimuusikat (vt noodinäide 2).

Laul "Sõduri kutse" (Lustilaulik 1999, nr 266) on mängitud akordionil. Laulu esimene, kolmest helist koosnev takt kõlab pillimehel ühe pika tertsina, mis nagu rõhutaks loo mažoorset iseloomu. Edasi ta varieerib viisi, jaotades pikki lööke lühikesteks. Kuna sõnad puuduvad, ei takista miski pillimeest kujundamast instrumentaalvormi oma nägemuse järgi. Säilitades loo vormi ja üldstruktuuri, toob ta sisse puhtinstrumentaalseid nüansse, mis iseloomustavad just seda pilli, millel ta parasjagu mängib. Pillimehed, kes on sisemiselt orienteerunud laulusõnadele, ei saa eriti midagi muuta, aga nende käe all, kes ei ole laulus kinni, võib tuntud lugu teha huvitavaid pöördeid. 

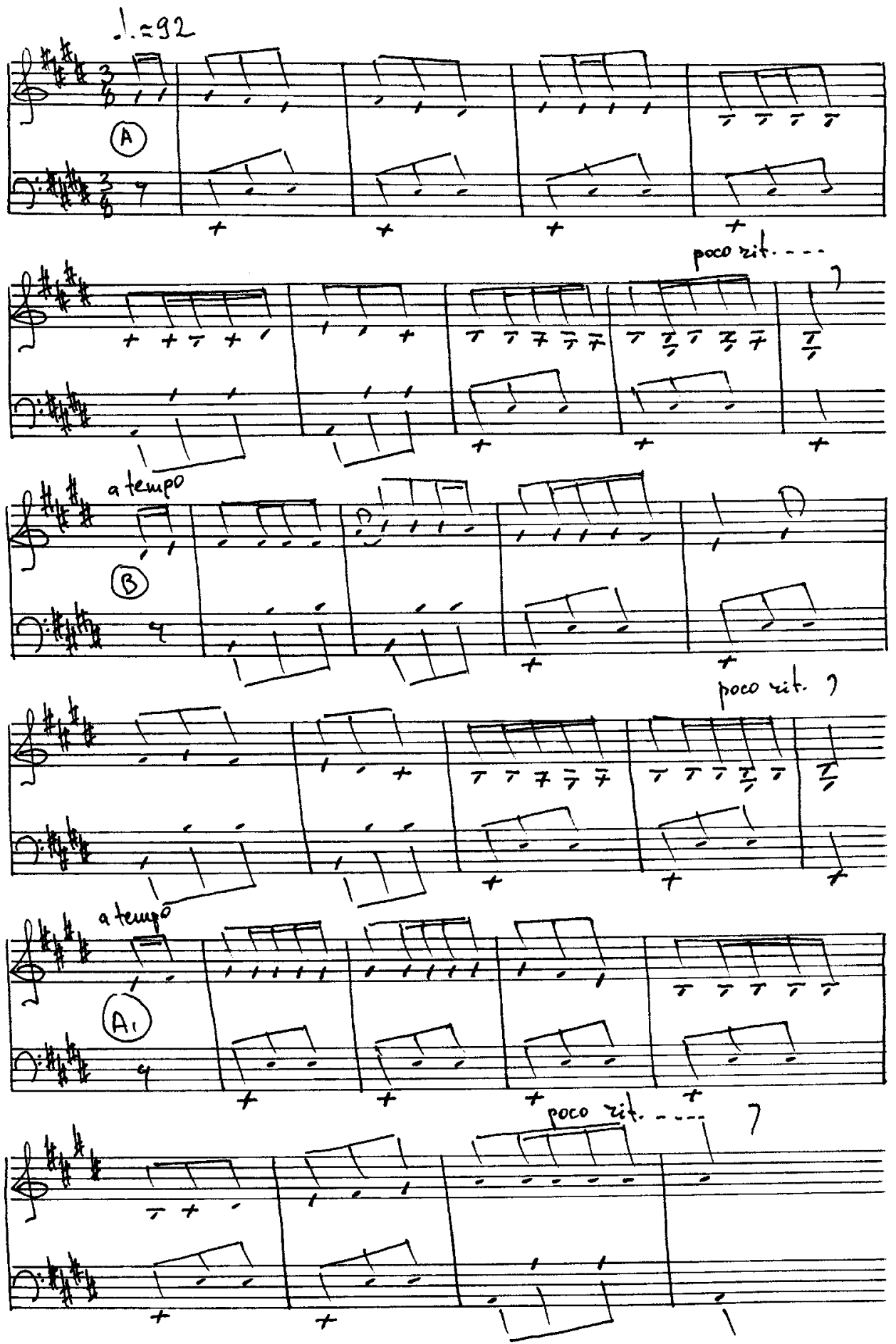

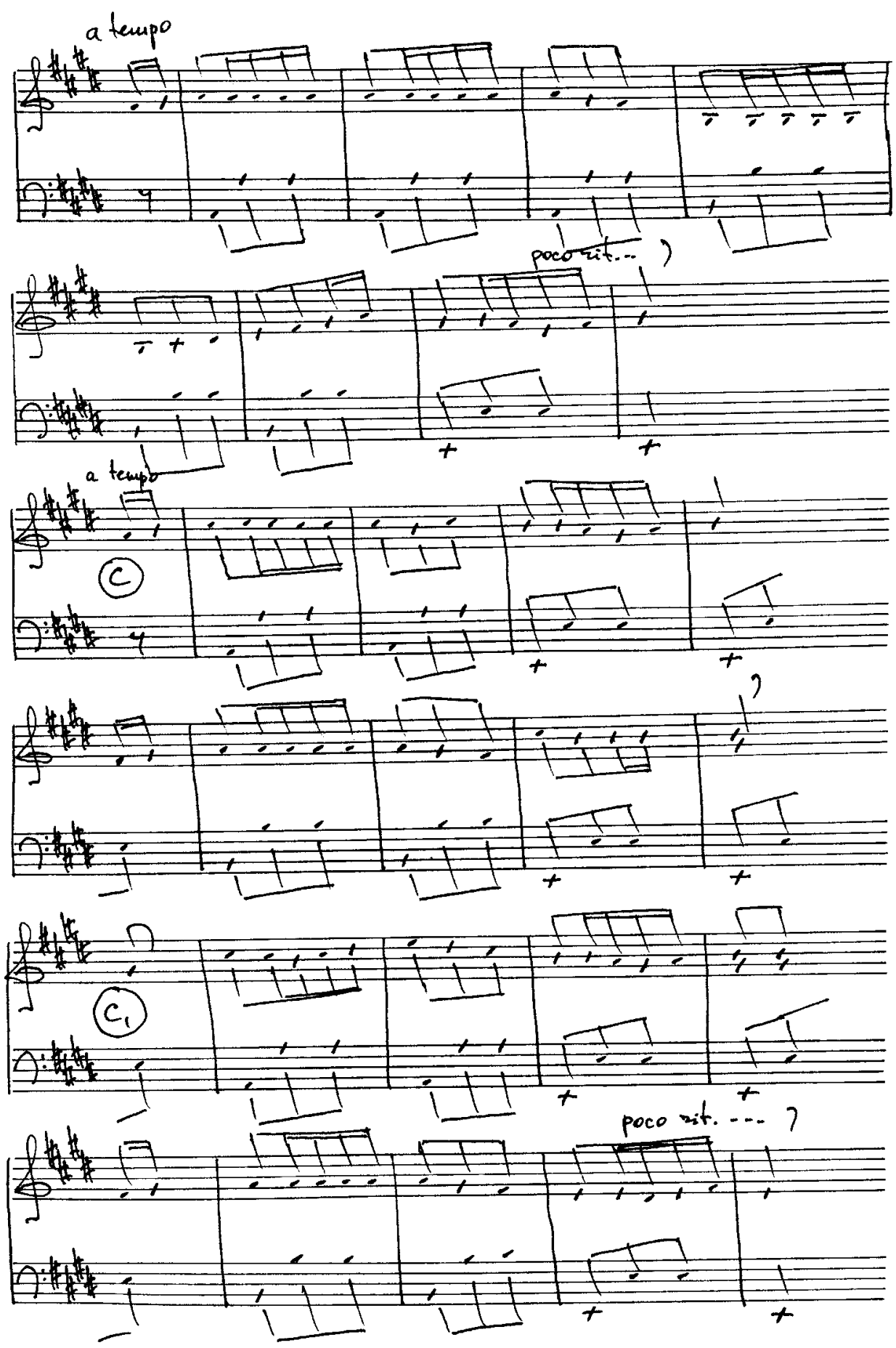

Noodinäide 1. 
$I=92$

$G$

D

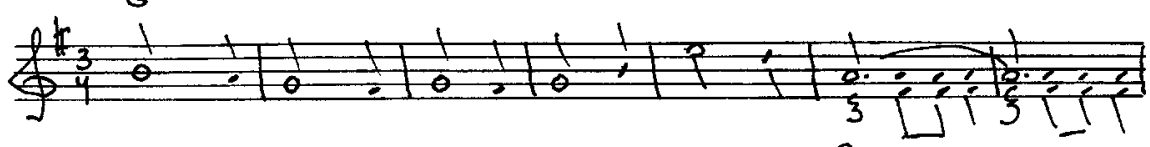

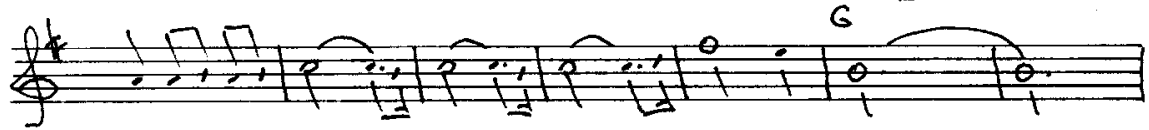

D

草,

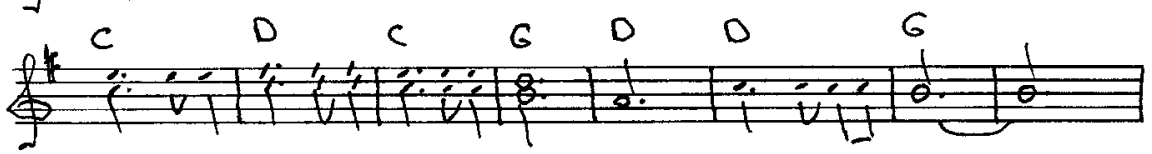

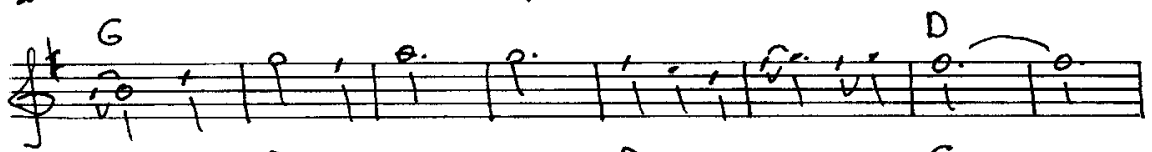

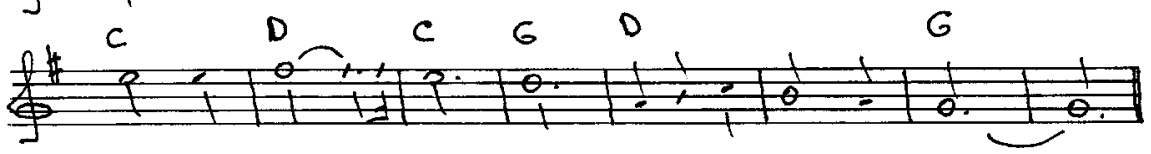

Noodinäide 2.
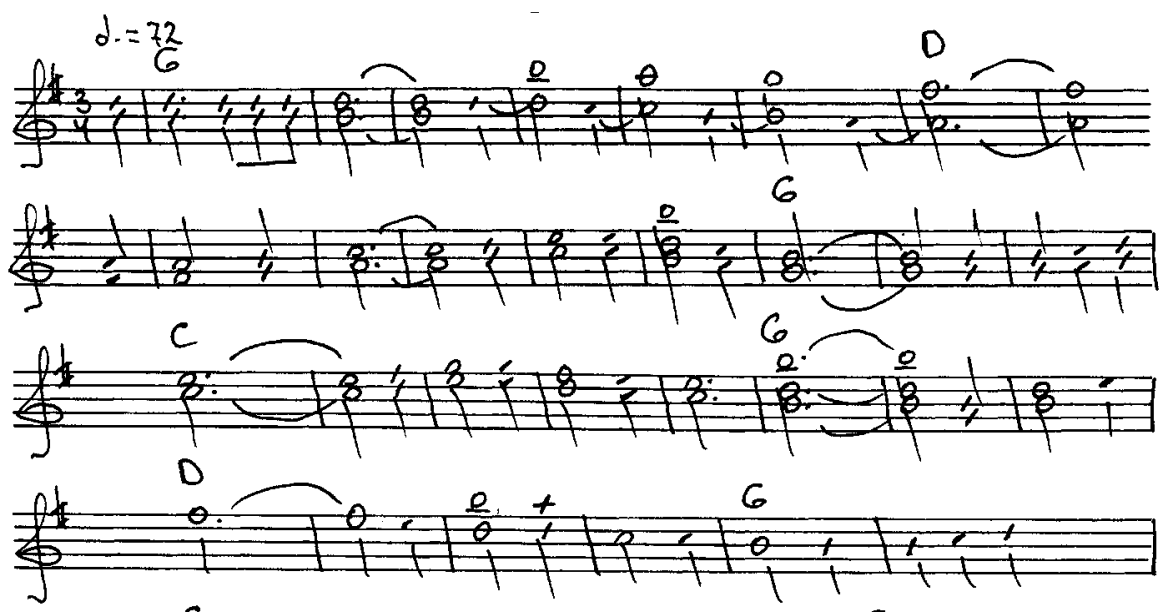

+

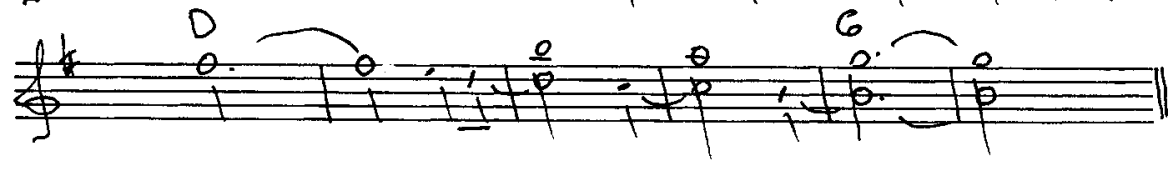

Noodinäide 3. 
Ilmar Hellamaa mängitud kandlepala "Kitarr mul käes ja mantel üle õla" (Lustilaulik 1999, nr 49) kannab populaarse rahvaliku laulu nime, kuid muud ühist on nende vahel raske leida. See on täiesti uus lugu. Ainult kusagil kaugel kuuldub nimilauluga sarnaseid intonatsioone. Kui pillimees nimetaks lugu kuidagi teisiti, oleks seost märgata kaunis võimatu. Võime julgesti väita, et tegemist on originaalse instrumentaalpalaga (vt noodinäide 3).

Rahvalikku valsiviisi "Viljandi paadimees" (RKM, Mgn ER $8 \mathrm{nr}$ 2) mängib Otepää kandlemees Ivo Kongot valsi tempost tunduvalt kiiremini. Loo struktuuri on järgitud täpselt, kuid pikad vältused, välja arvatud tugitoonid, liigenduvad lühikesteks. Lauluviisi suured hüpped on täidetud astmelise liikumise käikudega. Sujuv astmeline liikumine, hoolimata kiirest tempost, tekitab mulje valsilikkusest. Pillimees on lauluviisi arendanud instrumentaalpalaks.

Kuna Ivo Kongot mängib kooridega pillil, ${ }^{5}$ siis tema akordid kopeerivad akordioni faktuuri (vt noodinäide 4).

Esialgne analüüs näitab, et kandlel puudub repertuaar, mida esitatakse ainult sellel pillil. Kõiki kandlelugusid mängitakse ka lõótspillil ja akordionil ning vastupidi. Võib olla see ongi põhjus, miks matkib kandle akordisaade tihti lõôtspilli ja akordioni. Kannel, nagu lõôtspill ja akordiongi, on oma repertuaari saanud rahvalikult laulult. Zoltán Kodály sõnad, et rahvas mängib sedasama, mida laulab, on eesti rahvalike lugude puhul täiesti maksvad.

Omalooming on tähtis individuaalse repertuaari täienemise allikas, kuid lugusid, mille tuntust ei aita võimenda raadio ega televisioon, ei mängi enamasti keegi peale autori enda. Erandeid tunduvad olevat väga harvad. Näitena võiks tuua lõõtsamängija Karl Kikka lugusid, mis esinevad ka mõnede teiste pillimeeste repertuaaris.

\section{Kõrvalepõige teise kultuuri}

Oma varasemad uurimistööd olen kirjutanud tadžiki ja pamiiri rahvamuusika vallas. Esialgu oligi mul kavas samm-sammult, koos artikli edenemisega, võrrelda eesti rahvamuusika sisemisi arenguid tadžiki ja pamiiri rahvamuusika vastavate nähtudega. Töö käigus selgus, et teha seda jooksvalt ei ole otstarbekas: erinevaid kultuuriruume puudutavad osad oleksid hakanud üksteisele "jalgu jääma". Mingi taust võrdlusteks tundub ometi vajalik, seepärast esitan algselt plaanitu terviklikult.

Esmalt tuleb rõhutada, et tadžiki rahvamuusikas puuduvad laulude instrumentaalversioonid. Instrumendil mängitakse laulude saadet ja pillimehe omaloomingulisi viise. Tantsumuusika euroopalikus mõistes puudub hoopiski, tantse saadab suure tamburiini rütmiline põrin. 

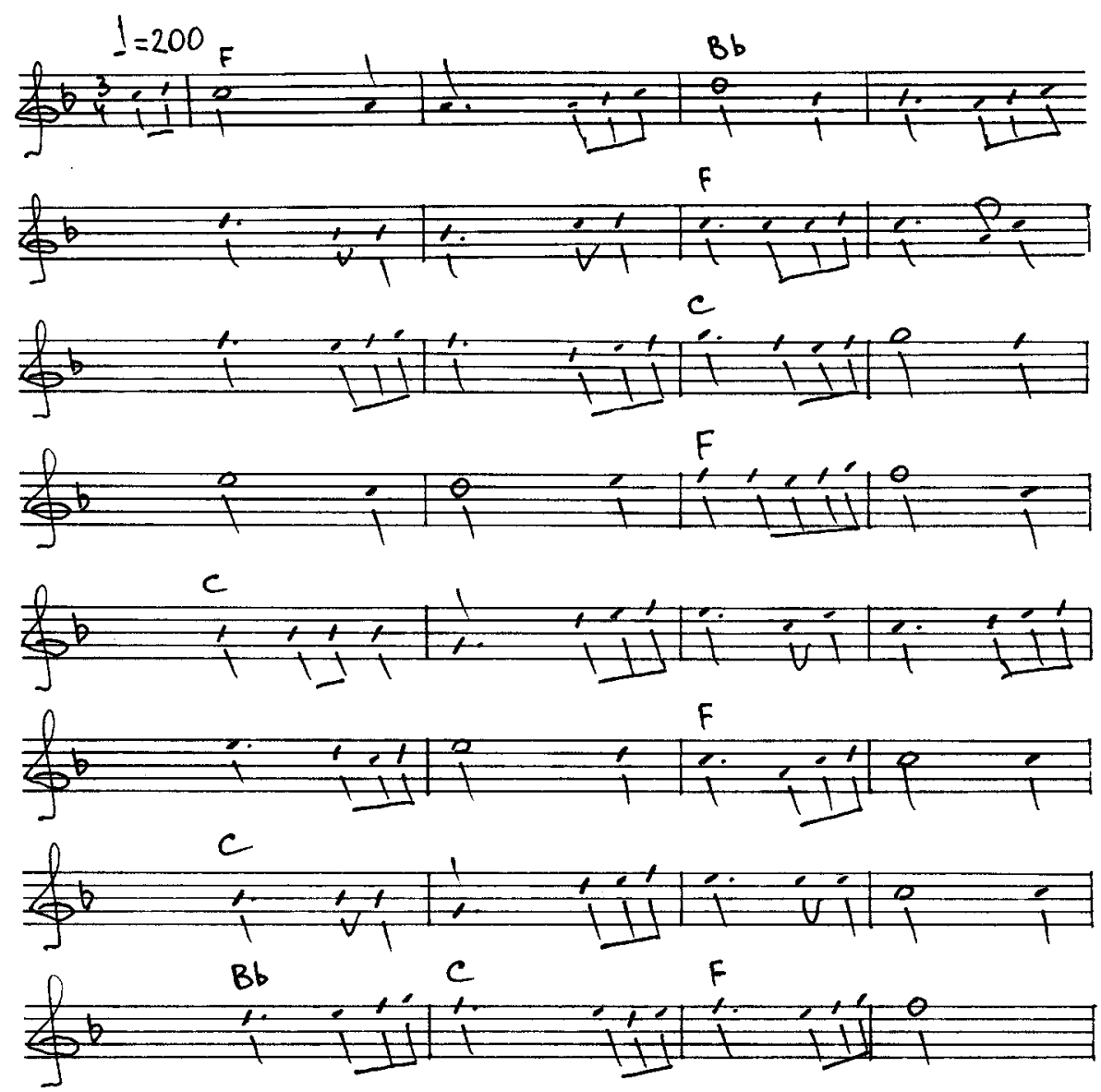

Noodinäide 4.

Tõmmata eraldusjooni tadžiki rahvamuusika kihistuste vahele J. Aaviku mõistes oleks võimalik äärmise tinglikkusega. Esimesed, 1909. aastal Riias välja antud grammofoniplaadile salvestatud tadžiki lauluviisid kuuluvad tänapäevalgi rahvamuusikute püsirepertuaari hulka. Juba seegi asjaolu teeb võrdlemise raskeks, sest eesti rahvapärane muusika on sama aja jooksul teinud läbi suuri muutusi.

Tadžiki rahvamuusika vanemast kihistusest on töölaulud samahästi kui kadunud. Neid veel mäletatakse, kuid neid esitavad ainult asjaarmastajate folkloorirühmad laval. ${ }^{6}$ Elujõu on säilitanud pulma- ja hällilaulud, samuti lüürilised laulud, mille viise on erilises noodikirjas üles märgitud juba palju sajandeid tagasi. Pean silmas rahvaviise, mida koondab "Šašmakom" - vokaal- ja instrumentaalpaladest koosnev kuueosaline tsükkel, mis sisaldab kokku 252 meloodiat. Kõik kuus osa - makomi - rühmituvad omakorda alajaotusteks. 
Ühe makomi kõik meloodiad kõlavad ühes ja samas laadis. "Šašmakomi" meloodiaid on hakatud nimetama klassikaliseks muusikaks. ${ }^{7}$

"Šašmakomi" viisid ei ole sõnadega jäigalt seotud. Igaüks kasutab lauldes just seda viisi ja värsse, mis talle sobivaina näivad. Sedasama vabadust tundis eesti vanem rahvalaul: laulja võis laulda selle viisiga, millega soovis (Tampere 1999: 14).

Kaasaegse tadžiki rahvaliku laulu ülesehitus järgib vanu eeskujusid üsna täpselt. Välja arvatud “Šašmakom”, esitavad lauljad ainult iseenda loomingut. Mitte keegi, vähemalt mitte avalikult, ei laula kellegi teise loodud viise. Lauluviis on autorist lahutamatu ja läheb hauda koos temaga. Näiteks sobib Afganistanis elanud kõrgelt hinnatud tadžiki laulja Ahmad Zohir, kelle looming hõlmab ligikaudu 380 lauluviisi. Need siiani ülipopulaarsed viisid on praegu kättesaadavad ainult helikandjate varal. ${ }^{8}$

Tadžikkide lähimas naabruses elavate Pamiiri rahvaste muusikas valitseb selline pilt, nagu Eestis võis olla regiviiside õitseajal. Nii laulud, kui ka pillimuusika kõlavad tänapäevalgi kitsas ulatuses. Vokaal- ja instrumentaalmuusika omavaheline side on väga tugev. Suure osa pillimeeste repertuaarist moodustavadki traditsiooniliste laulude instrumentaalversioonid.

\section{Kaks näidet repertuaari kujunemisest}

\section{Sulev*}

Jutuajamine vana tuttava, Viljandi mehe Suleviga sai alguse sellest, et kohtasin teda tänaval, akordionikast käes. Keegi oli toonud talle pilli parandada, nüüd oli ta seda omanikule tagasi viimas. Küsisin, kas ta ka ise akordioni mängib ja vastus oli, et muidugi. Rääkisime pikalt: mina pärisin ja tema vastas. Esitan siin jutuajamise sisu, küsimusi märkimata - neist saab vastuste põhjal niigi aimu.

See Saraatov või mis ta on siin kastis, kõlbab mängida küll. Täitsa hea pill. Mulle meeldib Weltmeister. Ah itaalia pillid? Noh, need on rohkem orkestripillid.

Meil Rebastekülas oli vanasti hulga pillimehi: ristiisa mängis ja [loetleb] - veel viis meest. Viiulit mängis ka paar tükki. Kannelt mängiti ka, mul oli ka kannel. Vana tüüpi, ilma koorideta. Keeli oli ikka rohkem kui kakskümmend. Lühikesed keeled enda poole, parema käega tõmbad viit, vasakuga bassi. Täpselt samu lugusid sai mängitud, mis pilliga [akordioni- 
ga]. Igasuguseid pille olen proovinud, kitarri ja kontrabassi. Vanasti sai kultuurimajas käidud.

Lõõtspilli ma olen ainult proovinud, mängitud sai ikka akordioni. Lõõtsmehi ei ole palju. Üks minu sõber, tema mängib kõiki pille, tal on Teppo lõots. Väga ilusa häälega pill. Sellele sobib hästi helirauda [trianglit] juurde lü̈̈a, ma vahel olen löönud. Varem oli tal liblik ${ }^{9}$, kokku surudes ja lahti tõmmates on hääl teine.

Ei, nooti ma ei tunne. Ükski pillimees ei tunne nooti. Lood õppisin ära laulikute järgi. Ei, nooti neis ei ole, viisi ma teadsin. Sõnad tuli ära õppida. Mina mängin, mis meeldib. "Viljandi paadimees", “Üks vanamees raius üht jämedat puud”, "Mets mühiseb”, "Kas mäletad kevadet õites”-ikka neid vanu asju. Ah, Valgret? Varem ehk olengi mänginud, nü̈̈d ei ole meeles need lood.

Praegu ma enam ei mängi, sõrmed on kanged. Aga kui vaja, saab ikka lugu ära tõmmatud. Alles hilja käisin maal poja sünnipäeval. Seal on üks vana Ohner, ei ole eriti hea mark. Ikka neid vanu lugusid mängisin. Rahvale meeldisid küll.

Jah, poeg mängib ka ja tütar samuti. Tütar hakkas nelja aastaselt pihta. Kuulis raadiost lugu ja hakkas klahvisid pidi otsima. Siis sai teda muidugi aidatud. Jah, nende lood on ikka needsamad vanad, mis minulgi. Uuema aja tümpsimine minule ei meeldi, ma arvan, et pojale-tütrele $k a$ mitte. Vahel tulevad naabrimehed garaa ži juurde kokku ja võtame väikse pitsi. Mul on seal pill, lasemegi loo lahti. Kõrtsiks nimetavad naised mu garaaži.

Ah, kunas kannelt mängin? Viiskümmend aastat tagasi mängisin viimati. Kas sõrmed leiavadki keele enam üles.

Jääb üle lisada, et Sulev on sündinud 1936. aastal.

\section{Inge*}

7. juulil 2007. aastal kutsuti mind Inge Kalviku 50. aasta juubelile. Inge on Viljandi Paalalinna Gümnaasiumi tehniline töötaja. Ta on sündinud Setumaal, Meremäe valla Kiislova külas.

Tutvusin temaga kolm aastat tagasi, kui tema noorem poeg Martin hakkas kaasa tegema algkooliklasside näiteringis, kus minu osaks on lastele laulud kirjutada, selgeks õpetada ja fonogrammid sisse mängida. Igal aastal oleme 
lavastatud mõne lühikese lastemuusikali. Martini ema on väga aktiivne ja abistab näiteringi, millega suudab: õmbleb kostüüme, valmistab dekoratsioone ja muud vajalikku. Kõik need kolm aastat on ta koos Martiniga käinud proovidel. Aga see, et ta on ka muusikainimene, ilmnes alles tema juubelil.

Juubeliüritus toimus gümnaasiumi väikeses saalis. Külaliste hulgas oli Inge ema (sünd 1931, elab Setumaal), lapsed ning teised lähemad sugulased ja tuttavad, töö- ja kursusekaaslased (Inge õppis omal ajal agronoomiks).

Mõned Martini klassiõed, kes olid äsja lõpetanud 3. klassi, tervitasid oma head koolitädi eriliselt selleks puhuks kirjutatud lauluga. Veel enne kooliaasta lõppu tulid tüdrukud ja palusid, kas ma ei teeks neile ühe laulu, millega saaks sünnipäeval ette astuda.

Kui rahvas oli söönud-joonud, läks lahti lustipidu. Inge võttis kätte akordioni ja alustas laulu. Natukese aja pärast hakkas teda toetama sõbranna ja siis ka teised. See, kuidas musitseerimine käivitus ja jätkus, viis mõttele, et pillimehi võiks nimetada "rahvahulkade muusikaõpetajaiks". Saadeti laiali mõnest lehest koosnevad laulikud, et kaasa laulda saaksid ka need, kes sõnu peast ei tea. Kui need laulud läbi said, võttis Inge sõbranna välja käsitsi kirjutatud lauliku ja algas nö teine ring. Mõned keerutasid tantsu ja ülejäänud rahvas laulis. Kõik laulud olid valsirütmis - justnagu teadlikult valitud.

Väikese vaheaja järel kutsus Inge soovijaid võistu laulma. Koosviibijaile jagati kätte laulude nimekiri ja mängima pandi karaoke plaat. Esimesena võttis mikrofoni Inge tütar. Temale läks abiks Inge õemees Mart. Siis astusid üles nooremad sõbrannad. Kui lugu oli aeglasem, siis mõned paarid tantsisid.

Inge pole muusikat õppinud. Ta lõpetas Meremäe keskkooli ja seejärel Tallinna 4. Tehnikakooli. Minul see mängimine ja laulmine läinud geenidega isast. Pisik on sees, on ta ise ütelnud. Repertuaari ta on saanud raadiost, viimasel ajal Raadio Elmarist.

Mis meeldis, võtsin kassetti ja kirjutasin sõnad välja. Niigi õpin need lood kuulmise järgi. Siis istun pilliga kodus ja nuputan. Noote ma ei tunne. Ma vaatan teksti järgi. Kui tekst paistab tuttav, siis kuulmise järgi otsin viisi. Teine allikas on õppida teiste käest. Ja need on vanemad inimesed. Kolmas allikas on laulikud. Üks mu sõbranna elab Paides. Kui juhtume temaga kusagil seltskonnas kokku saama, siis laulame koos. Mulle meeldivad lustlikud lood, need jäävad külge. Valsirütm on väga meeldiv. Aga kui Martiniga õpime mingit laulu, siis võtan akordioni välja ja näitan temale ette. C-duuris on kerge - kõik valged klahvid. F-duuris ka veel saab, aga G-duuris on juba raskem.

Inge aktiivses repertuaaris on üle saja laulu. Hiljem tegin tutvust laulikutega, mida Inge mälu värskendajaina tarvitab. Paksude ja põhjalike Lustilaulikute 
kõrval leiab terve pesakonna õhemaid, nootideta vihikukesi: Kui Kungla rahvas..., Laule pulmadeks, Laulurõõm ja mõni teinegi veel.

Inge ise ei ole proovinud laulusõnu või viisi teha. Kuid ta kinnitab minu arvamust, et sõnadel on suur, vahest isegi suurem tähtsus kui viisil. Kui sõnad meeldivad, võtan laulu vastu, kui ei meeldi, jääb kõrvale, ütleb Inge.

Sellest, kuidas ta pilliga tutvust tegi, jutustab Inge nii:

Minu isa mängis puhkpilliorkestris pasunat. Vanaisa mängis kannelt. See oli viisikannel, ainult täiesti korrast ära. Laste jaoks oli kodus pisike nelja bassiga akordion, mille kallal ma tihti nuputasin. Karja minnes vôtsin pilli kaasas. Läksime alati kuus või pool seitse hommikul kuni üheteistkümneni. Seal istusin ja muudkui mängisin, otsisin. Külamemmede käest kirjutasin sõnu. Paber-pliiats oli mul alati kaasas. Ja kui sõnad olid juba kirjas, ülejäänud oli käkitegu. Kui olin kuuenda klassi õpilane, ostis isa mulle 80 bassiga akordioni. Ta tahtis küll panna mind muusikakooli, aga see oli väga kaugelt meilt. Nii jäi see ära.

Paasapühal käiakse kirikus ja mälestatakse oma sugulasi. Võeti pitsi ka. Esimesel õhtul peeti kirmaski Lepa külas. Söögid-joogid võeti kaasas ja kella viie-kuue paiku hakkas pidu, mis läks tihti hommikuni välja. Seal olid lõotsamängijad, kandlemängijad ka. See oli minu rahvalike lugude kool. Varem, nõukogude ajal veel peeti pidusid ja rahvalik laul oli elujõuline. Tol ajal käis suguvõsa rohkem läbi ja igal peol alati mängiti ja lauldi. Aga siis tulid rasked ajad. Inimestel ei olnud materiaalseid võimalusi külalisi vastu võtta. Pillid vaikisid päris pikka aega. Nü̈̈d on muidugi tingimused avardunud. Rahvas tuleb kokku, peab pulmi, suguvõsad käivad läbi. Laul on jälle au sees. Kui ma lähen pulma või piduõhtule, on mul Weltmeister alati kaasas. Kui kutsutud pillimehed puhkavad, võtan pilli välja ja lauluviisi üles. Mida laulda, see oleneb muidugi seltskonnast. Enamasti valitakse temperamentsed lood, mis panevad jala patsuma ja keha liikuma. Mis paneb seltskonna elama. Ja muidugi väga palju oleneb laulu sõnadest.

Pillimees on ka Inge õemees Mart, kes mängib kitarri, akordioni ja süntesaatorit. Aeg-ajalt esineb ta lauljana väikese bändi saatel (löökpillid ja kitarrid), ise mängib rohkem süntesaatorit. Lood pärinevad Ivo Linna, Mati Nuude, ansamblite Suveniir ja Meie Mees, aga eriti Tarmo Pihlapi laulurepertuaarist.

Nad mõlemad, Inge ja Mart, arvavad, et kui rahvalikku laulu ei oleks, paneksid pillimehed oma pillid kotti.

Noortel ei paista erilist huvi olevat. Nemad laulavad ainult siis, kui vanem rahvas on otsa üles võtnud. Jääb loota, et kui nad vanemaks saavad 
ja noorte hulgas istuvad, võtavad nemad laulu üles. Aga kas tõesti niimoodi juhtub, see on suur küsimus.

\section{Lõpetuseks}

Kokkuvõttes võib öelda, et rahvalik muusika, kuigi koduses miljöös kõlab siin ja seal, on sattunud täbarasse seisu. Agressiivne moodsa muusika voolus surub tagasihoidlikumad viisid kõrvale. Enam ei ole soliidne, kui kokkutulnud seltskond laulab pilli saatel "Viljandi paadimeest". Vaja läheb mehi kitarride, trummide ja helitehnikaga, aga kokkutulnud on publik, kellele ette lauldakse. Ometi teadvustavad rahvad ennast üsna tunduval määral just eelkäivate põlvede muusikapärandi kaudu.

Nihkeid muusikalistes eelistustes, rahvapärases repertuaaris või üldse sellise repertuaari kadumise tingib tänapäeval mitte niivõrd sisemine areng, vaid peale tungivate moevoolude surve. Tahtmatult meenub hernhuutluse osa rahvalaulu vanema kihistuse hääbumise kiirendajana. Öeldes Veljo Tormise üle kolmekümne aastat tagasi kirja pandud sõnadega: Areng läheb edasi siit, kus me p r a e g $u$ [essee autori sõrendus - G. J.] oleme, meiega tuleb kaasa kõik see, mis juba olemas, ükskõik kust see kunagi pärit olnud (mis kultuur see olnud.) Me peame ainult teadlikud olema, mis meil on ja mida pole ning mis unarusse jäetud. (Tormis 2007: 13-14).

Pillimeeste repertuaar on stabiilses seisus ja arhiivi kogunenud salvestised näitavad, et juba pikka aega. Mängitavamad lood pärinevad sõjaeelsest ajast, pillimehed nagu polekski nõukogude perioodil elanud. 1981. aastal Enno Kunnuse mängitud lugude nimekirjas ma leidsin märksõna "Eesti hümn”. Et kandlemees oli üsna noor, neljakümne viie aastane mees, ma ei kahelnudki, et tegemist on ENSV hümniga. Aga ei, salvestatud oli tõelise Eesti Vabariigi hümn. Kuigi rahvapärane repertuaar ei täiene uute lugudega, ei ole pillimuusika päriselt kivistunud seisus. Andekaimad pillimehed tunnetavad muusikat omamoodi, nende käe all rahvalik laul teiseneb, varieerub, aga mõnikord kukub välja uue loona, mida eeskujuga jääb siduma ainult nimetus.

Viimasel ajal on edu saatnud vanemat rahvaviisi. Seda õpitakse ja esitatakse, kuid see kipub jääma rohkem suviste muusikaürituste tõmbenumbriks. Raske ongi ette kujutada, et kord juba kadunud kunsti saaks uuesti üles äratada ja panna elama täisverelist elu. Tunduvalt perspektiivikam oleks alal hoida ja virgutada seda, millel on veel siiani olemas massiline kandepind rahvalikku laulu ja pillimängu. Iseasi, kas keegi teine, peale laulu- ja pillimeeste endi, loevad seda väärtuseks, millest tasub kinni hoida. 


\section{Kommentaarid}

* 2007. aasta suvel lindistatud intervjuude täisversioon on autori valduses.

${ }^{1}$ Eeskätt pean silmas Juhan Zeigeri monograafiat Eesti rahvaviisid, Herbert Tampere kogumikku Eesti rahvapillid ja rahvatantsud ja viieosalist Eesti rahvalaule viisidega, sama autori Eesti rahvaviiside antoloogiat ning Rudolf Põldmäe ja Herbert Tampere kogumikku Valimik eesti rahvatantse.

2 Palestiina linnas Gazas laastati 2006. aastal prohvet Muhamedi vanaisa haud, kuna puhas islam ei lubavat mitte mingisuguse materiaalse mälestise austamist. Massilise ulatuse on kultuurimälestiste hävitamine võtnud Saudi-Araabias, kus hinnanguliselt on purustatud $90 \%$ ajaloolise väärtusega mošeesid ja muid arhitektuurimälestisi. www.islam.ru/pressclub/histori/unisnad.

3 Samalaadseid kirikukellade imitatsioone on fikseeritud Karjala kanneldajate esituses. Nii setusid kui ka karjalasi inspireerib õigeusu kirikute meloodiline kellamäng.

4 Silma hakkas, et Lustilaulikus I on A. Vintersi populaarne rahvalik laul "Viljandi paadimees" toodud defektselt. Refrääni pikad vältused on kahe takti ulatuses killustunud lühemaiks, mistõttu on rikutud viini valsi taoliselt voogava muusikapala meetrum. Seda põhjustab refrääni teisele reale ilmunud liigne kolmesilbiline sõna "ilusad", mida ei leidu J. Pori loodud tekstis. Ma ei taha öelda, et laulja ei tohi sisse viia mingeid muutusi, kuid trükistes tuleks muusikapalad ja laulutekstid anda originaalkujul.

5 Kandletüüp, millel tsitrite eeskujul on peale viisikeelte kolm või rohkemgi akordikeelte komplekti.

6 Tadžiki folkloorirühmade all pean silmas klubide ja kultuurimajade juures tegutsevaid isetegevuslikke kollektiive, kes teatraliseeritud vormis näitavad, kuidas vanasti lõigati vilja või peeti pulmi ja laulavad sealjuures vastavaid laule.

7 Tadžiki muusikakultuur jaguneb piirkondlikult kaheks provintsiks, millede tinglikuks piiriks loetakse Hissoori mäeahelikku. Lõunas, kaasa arvatud tadžikkide alad Põhja-Afganistanis, hinnatakse koolitamata ja loomulikku, rahulikult kõlavat pingestamata häält, mis enamasti jääb keskmise registri piiresse. Põhja pool, kus tooni annavad Sarafs̃oni jõe orus paiknevad iidsed linnad Buhhaara ja Samarkand, valitseb kohustusliku kulminatsiooniga, bel canto sarnane esitusviis. Siinkohal tadžiki muusika kohta öeldu kehtib suurel määral ka usbeki muusika kohta. Ajaloolises mõõtmes alles hiljuti tadžikkide hulka elama asunud usbekid sattusid kohaliku kultuuri mõju alla ja võtsid muu hulgas üle ka muusika.

${ }^{8}$ Ahmad Zohir mõrvati vene okupatsiooni ajal 1981. aastal. Keegi Ahmad Josir Bahor on traditsiooni hüljanud ja esineb Ahmad Zohiri lauludega mitmel pool, ka Euroopas. Kuna võimed ei lase lauljal tõusta eelkäija tasemele, tundub tema ettevõtmine pigem äri- kui muusikaprojektina.

9 Ilmselt on Sulevi kõnepruugis "liblik" Peterburis XX sajandi algupoolel valmistatud lõõtspill, mille nurkadele kinnitati lüüra- või liblikakujulised metallkaunistused (vt nt Teinbas 1994: 17). Teppo pilli ja libliklõõtspilli heli tekitamise põhimõte on ühesugune. 


\section{Allikad ja kirjandus}

\section{Allikad}

RKM, Mgn II = Eesti TA Fr. R. Kreutzwaldi nim (Riikliku) Kirjandusmuuseumi (nüüd Eesti Kirjandusmuuseumi) rahvaluule osakond, magnetofonilindistused (mono).

RKM, Mgn ER = Eesti TA Fr. R. Kreutzwaldi nim (Riikliku) Kirjandusmuuseumi (nüüd Eesti Kirjandusmuuseumi) rahvaluule osakond, magnetofonilindistused, Eesti Raadio lindistused.

ERM = Eesti Rahva Muuseum

Hellamaa, Ilmar 2006. Kandlemeister. CD. Tallinn: I. Hellamaa.

\section{Kirjandus}

Aavik, Juhan 1965. Eesti muusika ajalugu I. Stockholm: Eesti Lauljaskond Rootsis.

Gnadenteich, Jaan 1995. Kodumaa kirikulugu: usuõpetuse õpperaamat. Tallinn: Logos. Ilja, Voldemar 1995. Vennastekoguduse (hernhuutluse) ajalugu Eestimaal (Põhja-Eesti). Tallinn: Logos.

Kalda, Elo 2001. Eesti kandlemängijad ja kandlepalad Eesti Kirjandusmuuseumi eesti rahvaluule arhiivi fonoteegis. Diplomitöö. Käsikiri. Viljandi Kultuurikolledž.

Lattik, Jaan 1960. Minu album: aja- ja eluloolisi lehekülgi. Toronto: Orto.

Lustilaulik I osa 2000. Tallinn.

Masing, Uku 1998. Eesti usund. Tartu: Ilmamaa.

Põldmäe, Rudolf 1988. Vennastekoguduse muusikaliselt tegevusest meie maal. Teater. Muusika. Kino. 3, lk 67-78.

Põldmäe, Rudolf \& Tampere, Herbert 1938. Valimik eesti rahvatantse. Tartu: Eesti Rahvaluule Arhiiv.

Särg, Taive 2001. Rahvamuusika mõiste kujunemisest - "rahva"teaduste ja musikoloogia vahel. Pärimusmuusika muutuvas ühiskonnas 1. Eesti Kirjandusmuuseumi etnomusikoloogia osakond.

Sünter, Aleksander 1997. Uuem (rahva) laul ja pillilood 60. aastate ja vanemate inimeste repertuaaris 1990ndatel Jaani kihelkonnas Saaremaal. Kursusetöö. Käsikiri. Viljandi Kultuurikolledž.

Tampere, Herbert 1999. Eesti rahvaviiside antoloogia. Tallinn: Eesti Keele Instituut.

Teinbas, Taavi 1994. Lõõtspillidest, lõôtspillimängust- ja mängijatest. Tallinn: Eesti Rahvakultuuri Arenduskeskus.

Tormis, Veljo 2007. Rahvalaul ja meie. Eesti Kirjandusmuuseum. 


\title{
Summary
}

\section{The Formation of the Folk Repertoire of Instrumental Musicians}

\author{
Guldžahon Jussufi
}

Key words: folk song, psaltery, accordion, musical creation, popular repertoire

Popular music, even though it can still be heard here and there in more casual atmosphere, has found itself in a bind. The aggressive flow of modern music has pushed the more modest tunes aside. People no longer sing along together to some traditional accompanied tune. A performance of popular music requires men with guitars, drums and sound systems, and the rest of the group no longer actively participate in music, but form an audience who is performed to. Nevertheless, ethnic identity is still very much constructed through the musical tradition of previous generations.

Shifts in musical preferences or popular repertoire, or the disappearance of the repertoire from active use are caused by the pressure of music trends rather than by the internal development of music. The repertoire of instrumental music is enjoying a stable period and the recordings contributed to the archives suggest that this has been the case for a long time. The more popular tales date back to the pre-war period, and during the Soviet period instrumental musicians appear to be absent altogether.

Even though popular repertoire does not expand with new pieces, instrumental music is not completely stagnated. The more talented musicians have different ways of sensing the music: in their interpretation the popular song alternates, varies, but sometimes emerges as a new song which resembles the old one only by the title.

Older folk tune has recently enjoyed considerable success. It is learned and performed but mostly tends to serve as a crowd puller at summer music events. It is indeed difficult to imagine that a lost art could be revived into active existence. It would be far more advantageous to preserve and promote what still has massive influence: popular song and instrumental music. Time will tell whether anyone other than singers and musicians themselves will consider it a value to hold on to. 